Article

\title{
Thermal Simulation of Ice Cellars as a Basis for Food Security and Energy Sustainability of Isolated Indigenous Communities in the Arctic
}

\author{
Alexey Maslakov ${ }^{1, *(\mathbb{D}}$, Ksenia Sotnikova ${ }^{1}$, Gleb Gribovskii ${ }^{2}$ and Dmitry Evlanov ${ }^{2}$ \\ 1 Faculty of Geography, Lomonosov Moscow State University, 119991 Moscow, Russia; \\ ks.sotnikova@geogr.msu.ru \\ 2 LLC STC Simmakers, 121205 Moscow, Russia; gleb.gribovskii@simmakers.ru (G.G.); \\ dmitri.evlanov@simmakers.ru (D.E.) \\ * Correspondence: alexey.maslakov@geogr.msu.ru; Tel.: +7-(985)-100-20-81
}

Citation: Maslakov, A.; Sotnikova, K.; Gribovskii, G.; Evlanov, D. Thermal Simulation of Ice Cellars as a Basis for Food Security and Energy Sustainability of Isolated Indigenous Communities in the Arctic. Energies 2022, 15, 972. https://doi.org/ 10.3390/en15030972

Academic Editor: Ogla Makarieva

Received: 1 December 2021

Accepted: 26 January 2022

Published: 28 January 2022

Publisher's Note: MDPI stays neutral with regard to jurisdictional claims in published maps and institutional affiliations.

Copyright: (c) 2022 by the authors. Licensee MDPI, Basel, Switzerland This article is an open access article distributed under the terms and conditions of the Creative Commons Attribution (CC BY) license (https:// creativecommons.org/licenses/by/ $4.0 /)$

\begin{abstract}
Underground storage facilities dug in permafrost, or ice cellars, are a natural means of preserving food in conditions of transport isolation and total energy dependence on imported fuel. In the context of rapidly changing natural conditions, such storage facilities become unstable due to warming and degradation of permafrost. Monitoring and modeling the thermal regime of permafrost soils around ice cellars will help assess the impact of predicted climatic changes and the effectiveness of engineering solutions to sustain these facilities. In this paper, we made an attempt to simulate and predict the thermal regime of permafrost around an ice cellar, located in the community of Lorino, NE Russia. We found out that by 2050 the depth of seasonal thawing of the soil above the storage facility will increase from 1.12-1.74 $\mathrm{m}$ to $1.19-2.53 \mathrm{~m}$, while the mean annual ground temperature will increase by only $0.5^{\circ} \mathrm{C}$, regardless of the climatic scenario. Results of the predictive simulation demonstrate significant but not critical changes of the thermal state of permafrost around the ice cellar. In fact, incorrect maintenance of the facility may have higher impact to its stability than climate changes. Some recommendations on preventive measures on increasing the ice cellar stability were provided.
\end{abstract}

Keywords: ice cellar; food security; energy sustainability; climate change adaptation; numerical simulation; permafrost; structural stability

\section{Introduction}

The indigenous peoples used to accustom its facilities to local climate conditions for thousands of years. Such vernacular buildings might serve as more effective for housing [1,2], fermenting [3] or multiple [4] purposes due to implementation of climate responsive design strategies. Indigenous peoples of the Arctic have also actively exploited resources of the cryosphere for many purposes, including economic and residential ones. Even in the early days of the humanity, Neanderthals used permafrost to store meat of the harvested prey: they used holes cut in the frozen ground [5]. Over thousands of years, people were developing techniques and methods of the permafrost utilization in various parts of the world [6]. Within the territory of the modern Russia, the peoples of the Far East and Siberia used permafrost for their needs most extensively, as well as residents of Alaska and the Canadian Arctic Archipelago. The underground ice cellars, also called ledniki, or Sigluaq in Iñupiat and Siqlugaq in Yupik, became widespread [7].

The territory of the Chukchi Peninsula (NE Russia) was once a part of the large paleogeographic region Beringia [8,9]; now it features the unique cultural legacy. During the 20th century, that region was experiencing the process of intensive economic development. Developing the local economy, they reorganized local communities into kolkhozs: stateowned collective agricultural enterprises established for reindeer herding and polar fox 
farming. Fox farming required facilities for the year-round storage of meat resulting from deceased foxes. For this purpose, large industrial ice cellars were constructed in permafrost in every community of the Chukchi peninsula in the 1950s and 1960s [10]. Those facilities were dug using heavy machinery for metro construction and were different in design and capacity depending on community population and the fox farm size. In this way, ice cellars in Chukotka differ from those in other regions [6] and represent a combination of traditional knowledge and modern technologies.

The modern-day climate warming in the Arctic [11,12] has affected the state of permafrost [13] and active layer [14] and, consequently, the facilities constructed in frozen ground including ice cellars [15]. Its detailed studies in the context of stability to external impacts were initiated recently $[16,17]$ and were moderated by recording structural descriptions, thermal monitoring and detection of cases of its collapse or flooding. For instance, Nyland et al. [18] revealed that the reasons of ice cellars collapsing in the Arctic are not only climate warming, but also geology, economic development and social issues.

Our recent study revealed that since the period of ice cellars construction, the mean annual air temperature (MAAT) in the Chukchi Peninsula has been increasing at an average rate of $0.7^{\circ} \mathrm{C}$ per decade [10]. Such dramatic changes in combination with common deterioration of social and economic conditions in the 1990s and 2000s resulted in collapse or flooding of the majority of ice cellars in the region. Today, the ice cellar in Lorino is one of two remaining ice cellars in the region. It is used for needs of almost 1000 indigenous habitants of the community, the biggest one in this area [19]. Goncharov et al. [20] classified such communities as autonomous villages-isolates with a population of over 500 habitants. These people live in remote, inaccessible areas and lack cultural and social facilities. Along with the isolated settlements in the areas of implementation of the resource projects, there are 87 settlements with the status of isolated communities in the Russian Arctic. Considering total dependence of these communities on external supply and extremely high energy tariffs [21], ice cellars might serve as natural food preservation facilities and mitigate the acute problem of food security and energy sustainability. Monitoring and simulating of thermal regime of such structures can become a tool to mitigate the negative consequences associated with the ongoing and expected permafrost degradation. It can also make a base for developing measures on maintenance of ice cellars under the changing climatic conditions.

The purpose of this study is to evaluate the predicted impact of climate changes on thermal regime and stability of the communal ice cellar located in the isolated settlement of Lorino, Chukotka Autonomous Okrug, Russia. To achieve this goal, we used the results of 5-year thermal monitoring in chambers of the ice cellar and methods of numerical simulation.

\section{Materials and Methods}

\subsection{Natural Environment of the Study Site}

The modeled entity is located at the territory of the Lorino settlement at Cape Lugren of the Chukchi Peninsula, which is confined to the residual of the sea-shore terrace adjacent to the Mechigmen Bay (Figure 1). The territory of the settlement is located within the border area between the Arctic and Subarctic marine climatic zones [22]. Due to the high barometric gradient resulting from cycles of warming and cooling of land and sea, the territory is characterized by strong winds. The effect of strong winds determines severe winters and irregular distribution of snow cover. Winter lasts for two-thirds of a year, and the average temperature for January ranges from -16 to $-20^{\circ} \mathrm{C}$. Summer is cloudy and chill, with average temperature for July from +8 to $+10^{\circ} \mathrm{C}$. In the course of a year, precipitation within the area is insignificant, $400 \mathrm{~mm}$ on average [23]. According to the Köppen-Geiger updated classification [24], the climate of the area under study is typical for the polar tundra. The same as the Chukchi Peninsula in the whole, Lorino lies upon the permafrost layer with a thickness up to $200 \mathrm{~m}$ [25]. The mean annual temperature of frozen ground within the bottom of the annual variation layer varies within the range of 
$-1-4{ }^{\circ} \mathrm{C}$ [26]. In general, frozen soils are characterized with solid cryogenic structure, with more of the rare laminated (in sandy loam) and basal (in peat) structures. [27,28]. The area under study locally demonstrates the cryogenic topography, mostly of thermokarst and thermo-erosional types [29]. The settlement forms a part of the Chukotka municipal district, one of the largest national settlements of the region: its population counts 980 residents [30], and $80 \%$ of them are representatives of indigenous peoples.

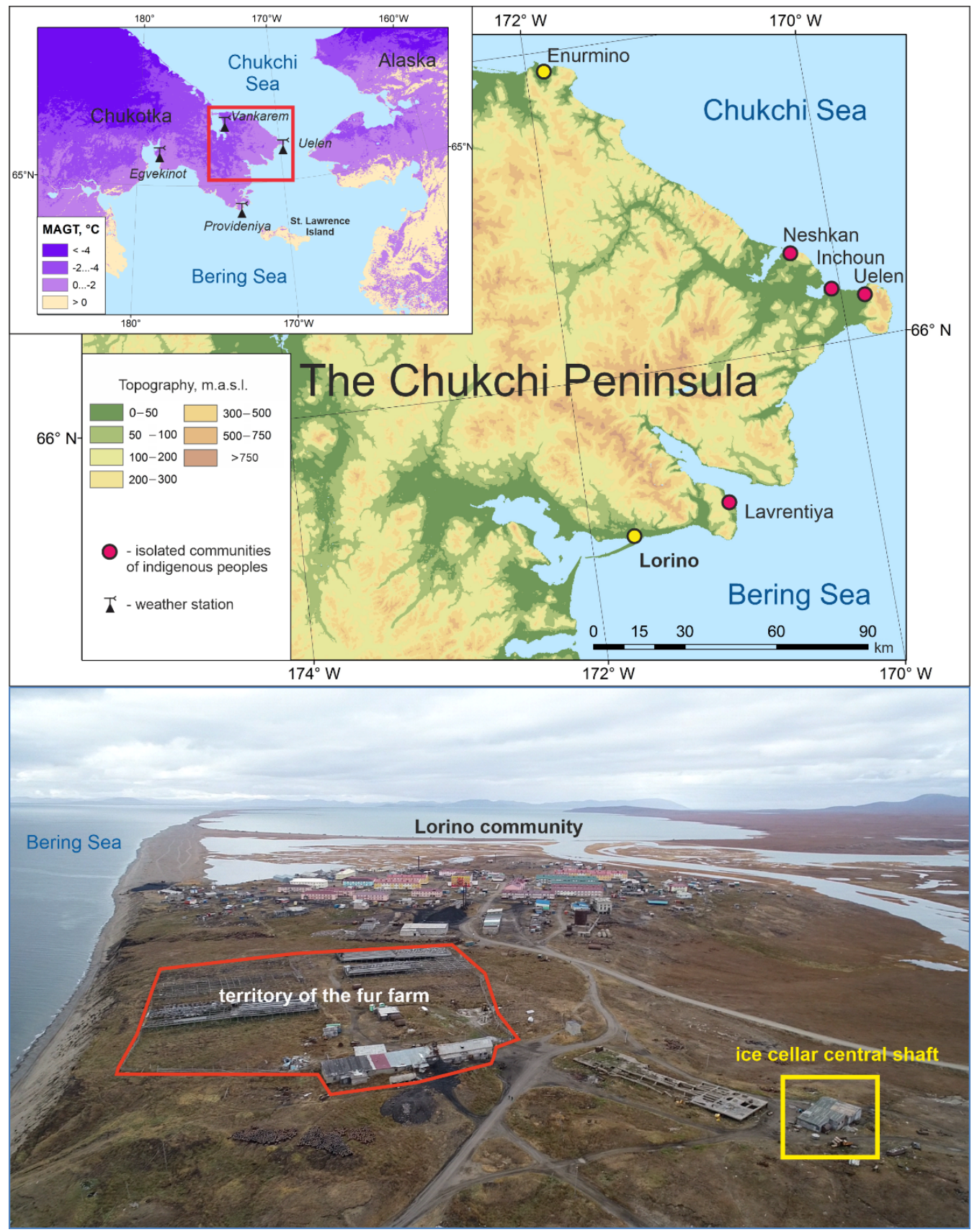

Figure 1. Location of the ice cellar in Lorino community.

\subsection{Modeling Object}

The community ice cellar in Lorino is a horizontal tunnel with lateral galleries and chambers dug into the residual of a Pleistocene marine terrace with a relative height of 15 to $20 \mathrm{~m}$. The terrace is composed of sands, underlain by loamy deposits and covered with a thin layer of peat (Figure 2). According to engineering survey reports [27], the ice cellar floor coincides with the loams/sands' boundary. The main structure of the ice cellar is a 
$159 \mathrm{~m}$ long tunnel, with a $50^{\circ}$ turn in its middle part from the straight direction. The cellar has a vertical $10 \mathrm{~m}$ height shaft, which is used for both meat transportation and winter ventilation (see Figure 2).

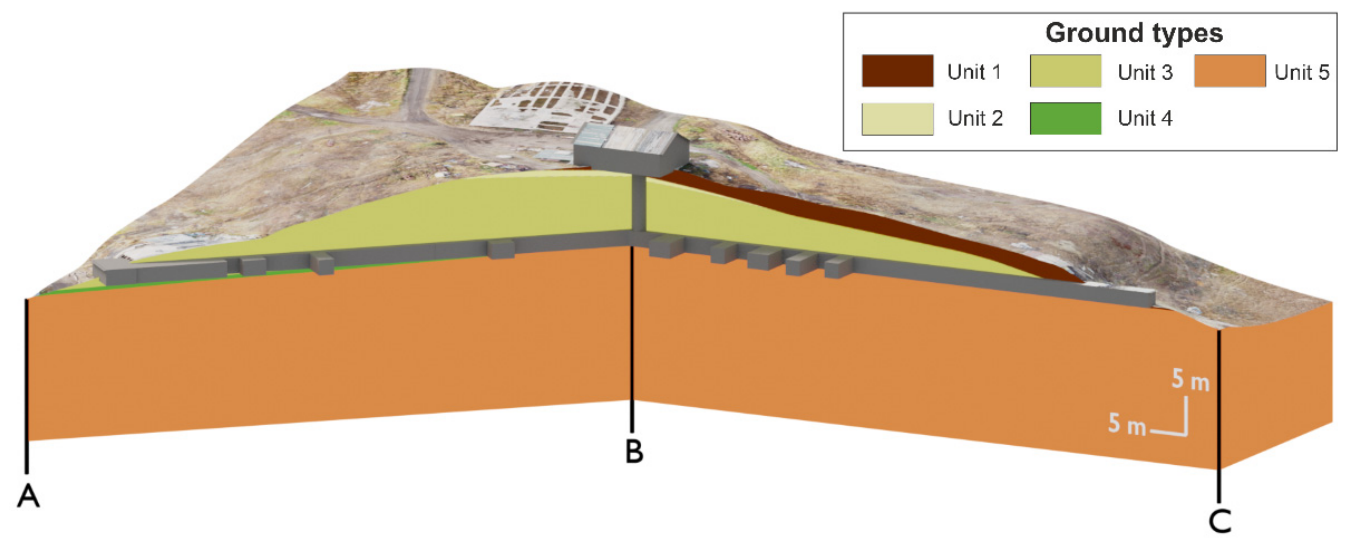

Figure 2. Geological composition of grounds surrounding the ice cellar in Lorino.

The local whale-hunting community takes a number of specific steps to maintain consistency of the ice cellar. To keep low temperatures inside the storage facilities, the ice cellar is ventilated with passive ventilation during the coldest months, these being January, February and March [10]. This measure is very efficient: it allows for the decreasing of the internal temperature by $4-6{ }^{\circ} \mathrm{C}$ during the cold season. To keep the inside temperature low, blocks of river ice are brought into chambers. Other important measures include repeated reconstruction of ice cellar structures and minimizing access to the cellar during the summer period.

\subsection{Study Materials}

\subsubsection{Ice Cellar Geometry and Topography Data}

The linear dimensions of the ice cellar and soil surface topography above the facility were described during field studies in 2019 and 2020. Parameters of the chambers and corridor were measured with a measuring tape. The orthophoto map and digital terrain model of the surrounding area were compiled using UAV DJI Phantom 4 Pro with further processing with the Agisoft Photoscan v. 1.2.5.2680 software. Detailed data on the ice cellar geometry and linear dimensions are provided in the previous study [10].

\subsubsection{Boundary Conditions Data}

Data on air temperature, wind speed and snow depth were obtained from a weather station in Uelen [31], which is situated in the extreme northeast of the Chukchi Peninsula in $114 \mathrm{~km}$ to the northeast from Lorino (Table 1). For the purpose of thermal analysis, we used data of the last 20 years and found the monthly average air temperature and 15-day averaged snow cover depth values.

After field studies conducted on the Lorino territory from 2014 to 2019, the temperature regime data for chambers of the ice cellar were obtained and used for calibration of the model [10].

Climate predictions for the period from 2041 to 2060 were taken from the 5th Assessment Report of IPCC, adapted for the territory of Russia [22,32,33]. For the Lorino area, we calculated the mean annual air temperature (MAAT) trends for the middle of 21st century (2041-2060) in comparison with the baseline period (1981-2000) as 0.0583, 0.0666 and $0.0833^{\circ} \mathrm{C} \cdot \mathrm{a}^{-1}$ for the RCP (Representative Concentrations Pathways) 2.6, RCP 4.5 and RCP 8.5 scenarios, respectively. 
Table 1. Monthly averaged air temperatures, wind speed and 2-week averaged snow depth for the period of 1999-2019, at the Uelen weather station [31].

\begin{tabular}{|c|c|c|c|c|}
\hline Month & Date & $\begin{array}{c}\text { Temperature } \\
T_{\text {ext }},{ }^{\circ} \mathrm{C}\end{array}$ & $\begin{array}{c}\text { Wind Speed } \\
v, \mathrm{~m} / \mathrm{s}\end{array}$ & $\begin{array}{c}\text { Snow Depth } \\
d, \mathrm{~m}\end{array}$ \\
\hline January & $\begin{array}{c}\text { 1st } \\
15 \text { th }\end{array}$ & -19.3 & 6.3 & $\begin{array}{l}0.28 \\
0.33\end{array}$ \\
\hline February & $\begin{array}{c}\text { 1st } \\
15 \text { th }\end{array}$ & -18.4 & 5.9 & $\begin{array}{l}0.40 \\
0.44\end{array}$ \\
\hline March & $\begin{array}{c}\text { 1st } \\
15 \text { th }\end{array}$ & -18.22 & 5.4 & $\begin{array}{l}0.52 \\
0.54\end{array}$ \\
\hline April & $\begin{array}{c}\text { 1st } \\
15 \text { th }\end{array}$ & -11.79 & 5.7 & $\begin{array}{l}0.59 \\
0.61\end{array}$ \\
\hline May & $\begin{array}{c}\text { 1st } \\
15 \text { th }\end{array}$ & -2.44 & 5.0 & $\begin{array}{l}0.63 \\
0.56\end{array}$ \\
\hline June & $\begin{array}{c}\text { 1st } \\
15 \text { th }\end{array}$ & 3.53 & 5.4 & $\begin{array}{c}0.28 \\
0\end{array}$ \\
\hline July & $\begin{array}{c}\text { 1st } \\
15 \text { th }\end{array}$ & 7.24 & 7.1 & $\begin{array}{l}0 \\
0\end{array}$ \\
\hline August & $\begin{array}{c}\text { 1st } \\
15 \text { th }\end{array}$ & 7.00 & 6.4 & $\begin{array}{l}0 \\
0\end{array}$ \\
\hline September & $\begin{array}{c}\text { 1st } \\
15 \text { th }\end{array}$ & 4.58 & 7.1 & $\begin{array}{l}0 \\
0\end{array}$ \\
\hline October & $\begin{array}{c}\text { 1st } \\
15 \text { th }\end{array}$ & 0.40 & 8.2 & $\begin{array}{c}0 \\
0.02\end{array}$ \\
\hline November & $\begin{array}{c}\text { 1st } \\
15 \text { th }\end{array}$ & -5.61 & 8.4 & $\begin{array}{l}0.05 \\
0.12\end{array}$ \\
\hline December & $\begin{array}{c}\text { 1st } \\
15 \text { th }\end{array}$ & -13.3 & 6.3 & $\begin{array}{l}0.16 \\
0.20\end{array}$ \\
\hline
\end{tabular}

\subsubsection{Soil Parameters Data}

Data on all thermophysical properties are provided in Table 2. Ground parameters were obtained from engineering survey reports, which were conducted within the Lorino settlement territory in 1979 and 1984 [27,28]. Clayey grounds (Unit 5) were defined as per SP 25.13330 [34], as the reports lack information about them.

Table 2. Ground thermophysical properties.

\begin{tabular}{|c|c|c|c|c|c|c|c|}
\hline \multirow{2}{*}{ Ground Types } & \multicolumn{2}{|c|}{ Thermal Conductivity, $\mathrm{W} /\left(\mathrm{m} \cdot{ }^{\circ} \mathrm{C}\right)$} & \multicolumn{2}{|c|}{ Heat Capacity, kJ/(m· $\left.{ }^{\circ} \mathrm{C}\right)$} & \multirow{2}{*}{$\begin{array}{c}\text { Water } \\
\text { Content } w_{t o t} \\
\text { p.u }\end{array}$} & \multirow{2}{*}{$\begin{array}{l}\text { Dry Soil } \\
\text { Density } \\
\rho, \mathrm{kg} / \mathrm{m}^{3}\end{array}$} & \multirow{2}{*}{$\begin{array}{l}\text { Ground } \\
\text { Freezing Point } \\
T_{b f},{ }^{\circ} \mathrm{C}\end{array}$} \\
\hline & Thawed $\lambda_{t h}$ & Frozen $\lambda_{f}$ & Thawed $C_{t h}$ & Frozen $C_{f}$ & & & \\
\hline Peat (Unit 1) & 1.04 & 1.67 & 3444 & 3150 & 0.5 & 93 & -0.4 \\
\hline Backfill (Unit 2) & 2.41 & 2.61 & 2990 & 2276 & 0.2 & 1680 & -0.6 \\
\hline Sand (Unit 3) & 2.03 & 2.32 & 3024 & 2184 & 0.29 & 1340 & -0.6 \\
\hline $\begin{array}{l}\text { Sand with } \\
\text { pebbles (Unit 4) }\end{array}$ & 1.80 & 2.00 & 3024 & 2184 & 0.29 & 1340 & -0.6 \\
\hline Clay (Unit 5) & 1.39 & 1.40 & 2780 & 2260 & 0.14 & 1770 & -0.6 \\
\hline
\end{tabular}

\subsubsection{Mathematical Model}

We used the Frost 3D 2021 software [35] to make a computer model of the ice cellar. Frost 3D allows us to perform numerical simulations of heat transfer processes in permafrost with the account for human-induced heat impact and climate changes. The calculation of non-stationary problem of heat distribution in 3D space is based on numerical solution of the heat Equation (1) using the finite difference method [36,37], with phase changes of wet ground due to the seasonal thawing and freezing: 


$$
C_{e f f}(T) \frac{\partial T}{\partial t}+\nabla(-\lambda(T) \nabla T)=0,
$$

where $T$ is the temperature, in ${ }^{\circ} \mathrm{C}$; $t$ is the time, in s; $C_{\text {eff }}(T)$ is the dependence of soil effective heat capacity on temperature (2), in $\mathrm{kJ} /\left(\mathrm{m}^{3} \cdot{ }^{\circ} \mathrm{C}\right) ; \lambda(T)$ is the dependence of soil thermal conductivity on temperature (3), in $\mathrm{W} /\left(\mathrm{m} \cdot{ }^{\circ} \mathrm{C}\right)$.

Change of thermal conductivity $\lambda$ (Equation (3)) and volumetric heat capacity $C$ (Equation (4)) of soil due to the temperature change, considering effect of variation of the unfrozen water content $w_{w}$ (Equation (5)) on thermophysical properties of soil in the range of freezing temperatures, can be described with the following equations $[38,39]$ :

$$
\begin{gathered}
C_{e f f}(T)=C(T)+L \frac{\mathrm{d} w_{u}}{\mathrm{~d} T}(T), \quad L=\rho w_{t o t} L_{w}, \\
\lambda(T)=\lambda_{f}\left(1-w_{w}(T)\right)+\lambda_{t h} w_{w}(T), \\
C(T)=C_{f}\left(1-w_{w}(T)\right)+C_{t h} w_{w}(T), \\
w_{w}(T)=\left\{\begin{array}{cc}
\frac{1}{1-A\left(T-T_{b f}\right)}, & T<T_{b f} \\
1, & T \geq T_{b f}
\end{array}\right.
\end{gathered}
$$

where $w_{w}(T)$ is the dependence of relative unfrozen water content in soil on temperature, in p.d.u.; $L$ is the volumetric latent heat of freezing of a soil, in $\mathrm{kJ} / \mathrm{m}^{3} ; L_{w}=334$ is the the specific latent heat of freezing of water, in $\mathrm{kJ} / \mathrm{kg} ; T_{b f}$ is the temperature of phase change of a soil, in ${ }^{\circ} \mathrm{C} ; A$ is the smoothing coefficient of $w_{w}$, which is equal to 30 for Unit 2 to 4 and 0.6046 for Unit 1 and 5 from Table 2.

When simulating processes in the ice cellar, we used the heat flux (Equation (6)) and conventional (Equation (7)) boundary conditions (BC):

$$
\begin{gathered}
\mathbf{n}(\lambda \nabla T)=q(t), \\
\mathbf{n}(\lambda \nabla T)=\alpha(t)\left(T_{\text {ext }}(t)-T\right)
\end{gathered}
$$

where $\alpha$ is the heat exchange coefficient, in $\mathrm{W} /\left(\mathrm{m} \cdot{ }^{\circ} \mathrm{C}\right) ; T_{\text {ext }}$ is the environment temperature, in ${ }^{\circ} \mathrm{C}$; $T$ is the soil temperature, in ${ }^{\circ} \mathrm{C}$; $q$ is the heat flux, in $\mathrm{W} / \mathrm{m}$.

The heat flux BC (Equation (6)) were applied to the boundaries of the workspace section under condition that heat flux is equal to zero. The conventional BC (Equation (7)) were used at the "air-soil" and "tunnel-ground" boundaries.

The resulting coefficient of heat exchange $\alpha$ (Equation (8)) for the "air-soil" boundary conditions with the account for snow parameters is found by the following equation:

$$
\alpha=1 /\left(\frac{1}{\alpha^{\prime}}+\frac{d(t)}{\lambda_{s}}\right)
$$

where $\alpha^{\prime}$ is the heat exchange coefficient with the account for the snow depth effect on heat exchange with atmosphere (9), in $\mathrm{W} /\left(\mathrm{m} \cdot{ }^{\circ} \mathrm{C}\right) ; \lambda_{s}$ is the thermal conductivity coefficient of snow, in $\mathrm{W} /\left(\mathrm{m} \cdot{ }^{\circ} \mathrm{C}\right)$.

The heat exchange coefficient of ground or snow surface with air depending on the wind speed $\mathrm{v}$ is found using the following formula [40]:

$$
\alpha^{\prime}=\left\{\begin{array}{cc}
6.16+4.19 v, & 0<v<5 \\
7.56 v^{0.78}, & 5 \leq v<30
\end{array}\right.
$$

The winter average thermal conductivity of snow $\lambda_{s}=0.3 \mathrm{~W} /\left(\mathrm{m} \cdot{ }^{\circ} \mathrm{C}\right)$ was found as the result of calibration and matching in natural environment. Calculation in natural environment was performed using the statistical data on average air temperature from 1945 to 2019 and on snow depth from 1966 to 2019. The condition for calibration was maintenance of the permafrost temperature at the depth of zero annual amplitude (ZAA). Temperature at the depth of ZAA is $-3{ }^{\circ} \mathrm{C}$, according to [28].

For the "tunnel-ground" $\mathrm{BC}$, we specified the monthly average temperature for the ventilation period from January to March, using the observation data of 2014 to 2019 [10]. The heat exchange coefficient was specified as $8.7 \mathrm{~W} /\left(\mathrm{m}^{2} \cdot{ }^{\circ} \mathrm{C}\right)$, which corresponds to the 
scenario of convective heat exchange indoors [41]. For other months, the coefficient is specified as $0 \mathrm{~W} /\left(\mathrm{m}^{2} \cdot{ }^{\circ} \mathrm{C}\right)$, which in conventional $\mathrm{BC}$ corresponds to the heat flux $\mathrm{BC}$ $q=0 \mathrm{~W} / \mathrm{m}^{2}$. This approach to the description of the "tunnel-ground" boundary conditions provides for taking into account the lower cooling effect of the ice cellar on the surrounding ground than in the natural environment.

\section{Results}

By preparing a computer model of the ice cellar with consequent numerical simulation in Frost 3D, we obtained the following results:

- 3D geological model of soils with the dimensions: length $145 \mathrm{~m}$, width $95 \mathrm{~m}$ and depth $30 \mathrm{~m}$ (see Figure 2);

- $\quad$ Finite difference mesh with the size 6.35 millions of nodes, where the min. and max. mesh step is equal to 0.2 and $1 \mathrm{~m}$, respectively;

- Results of simulation of thermal states of the soils on the 15 th of each month, as follows.

From 2014 to 2019 according to the reported weather data (see Section 3.1);

From 2020 to 2050 according to the averaged weather data for the last 20 years and to three scenarios of global warming (see Section 3.2).

The predictive thermal numerical simulation from 2014 to 2050 for the ice cellar model in Frost 3D was completed in $13 \mathrm{~min}$. The numerical solution was obtained using graphic card Nvidia RTX 2080 TI.

\subsection{Computer Model of Thermal Regime of the Ice Cellar}

We prepared a simulation for the period from 2014 to 2019 to obtain the initial temperature field for the further prediction of thermal conditions of soils from 2020 to 2050, taking into account various scenarios of the warming trend. Distributions of soil temperatures during the warm (15 September) and the cold (15 March) seasons of 2019 are given in Figure 3.
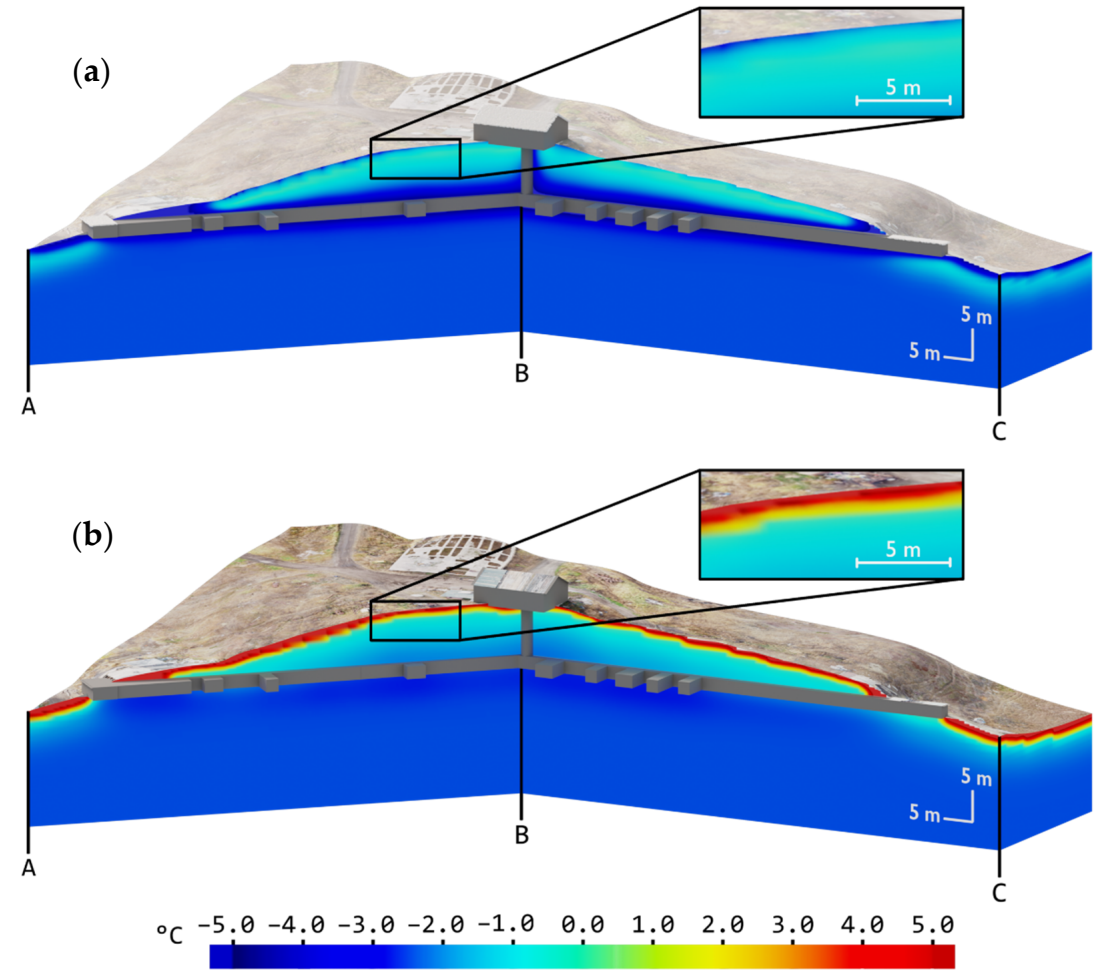

Figure 3. (a) Distributions of soil temperature around the ice cellar during the cold (15 March) season according to 2019 data. (b) Distributions of soil temperature around the ice cellar during the cold the warm (15 September) season according to 2019 data. 
Based on the computer simulation results for the ice cellar thermal state from 2014 to 2019, with the account for its ventilation during the cold months (January, February and March), we can see that the temperature of soils around chambers and corridors of the cellar remains below freezing point all the year round with fluctuations from -2 to $-5{ }^{\circ} \mathrm{C}$. The lowest temperatures can be observed during the months when ventilation is performed, and the warmest ones during the autumn months. The temperature of the frozen soils adjacent to the ice cellar but not under its thermal effect is $-3{ }^{\circ} \mathrm{C}$, which is close to the data for the frozen soil regimes obtained as the result of engineering surveys within the territory. The depth of seasonal thawing between the surface and the ice cellar varies within a range of 1.12 to $1.74 \mathrm{~m}$. The thermal state of soils close to the cellar walls also demonstrates good matching with the results of instrumental monitoring for the period from 2014 to 2019.

\subsection{Thermal State of Permafrost around the Ice Cellar by the Middle of the 21st Century}

As mentioned above, the MAAT trends for the middle of 21st century (2041-2060) in comparison with the baseline period (1981-2000) were found as 0.0583, 0.0666 and $0.0833^{\circ} \mathrm{C} \cdot \mathrm{a}^{-1}$ for RCP 2.6, RCP 4.5 and RCP 8.5 scenarios, respectively. These trends were applied for our calculations of the permafrost thermal state from 2020 to 2050. We assumed that the snow depth and variations of wind activity for the forecasted period would not have any significant impact on the permafrost temperature in comparison to the MAAT characteristic. Based on these data, we ran the model by 2050 and received the ground temperature distributions shown in Figure 4.

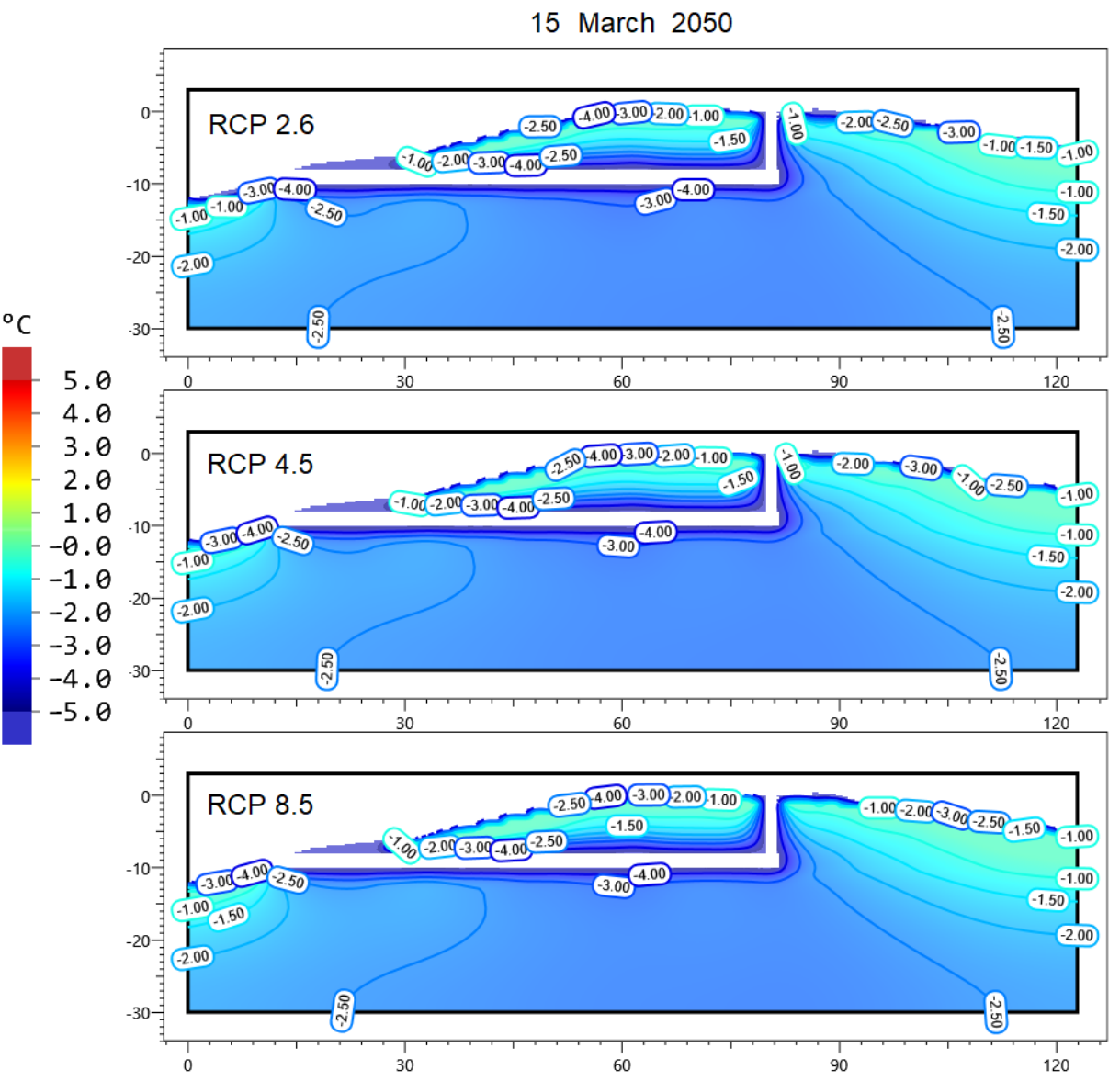

(a)

Figure 4. Cont. 
15 September 2050
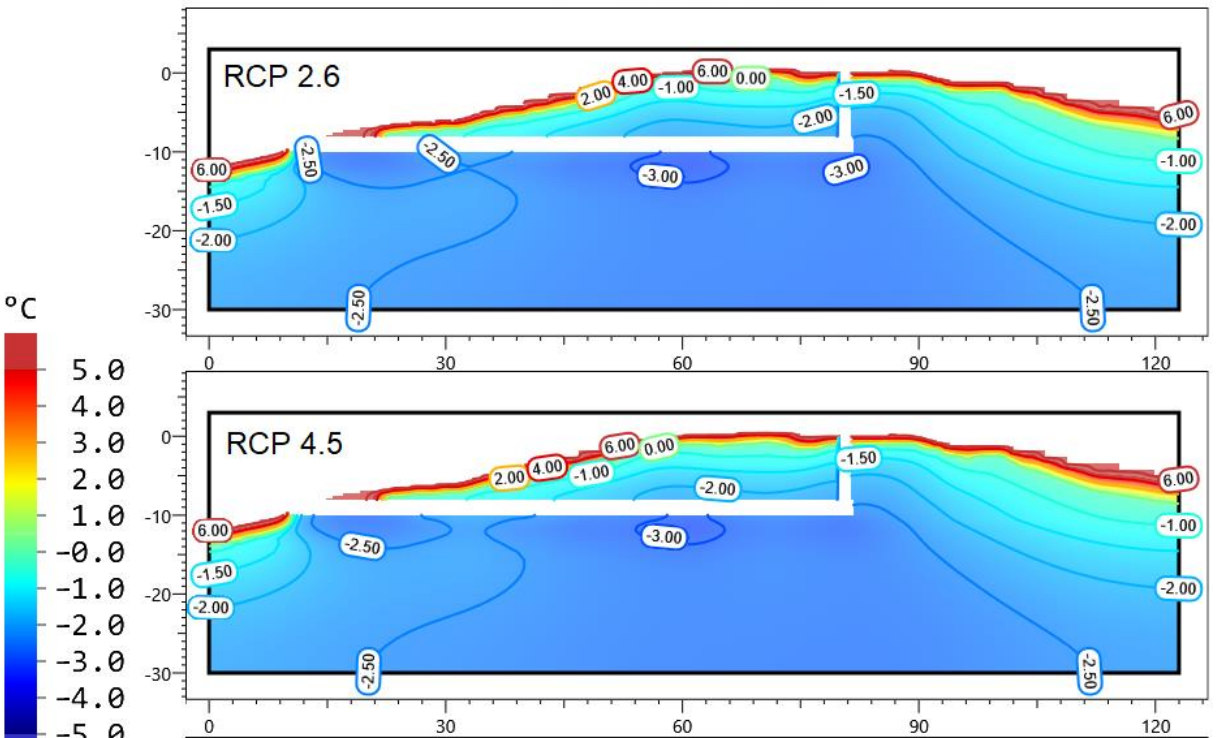

$-5.0$

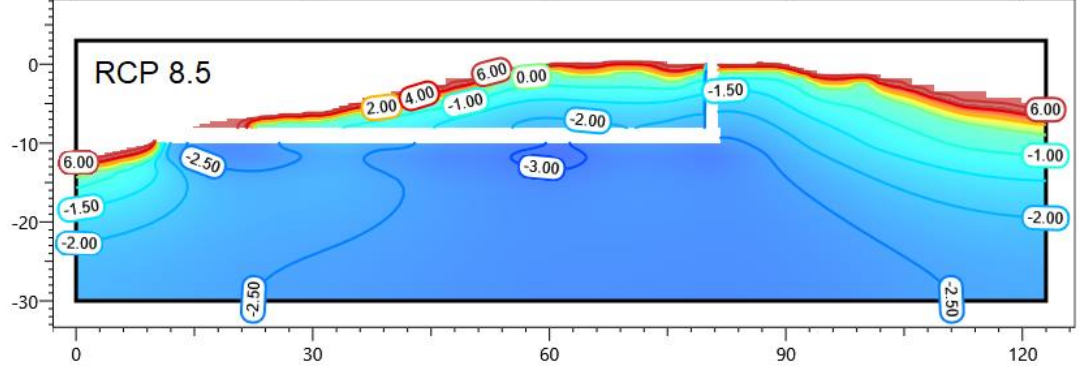

(b)

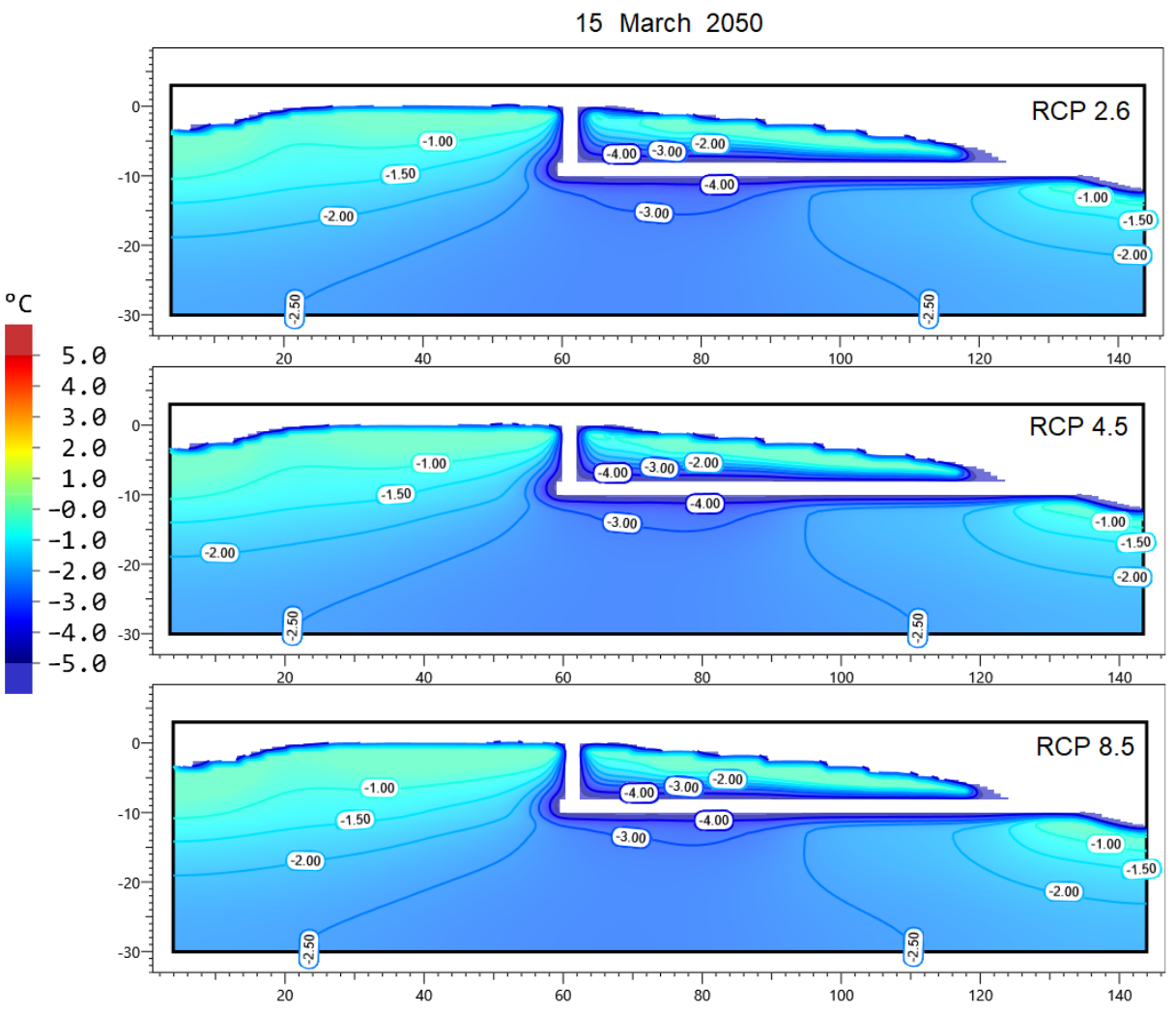

(c)

Figure 4. Cont. 


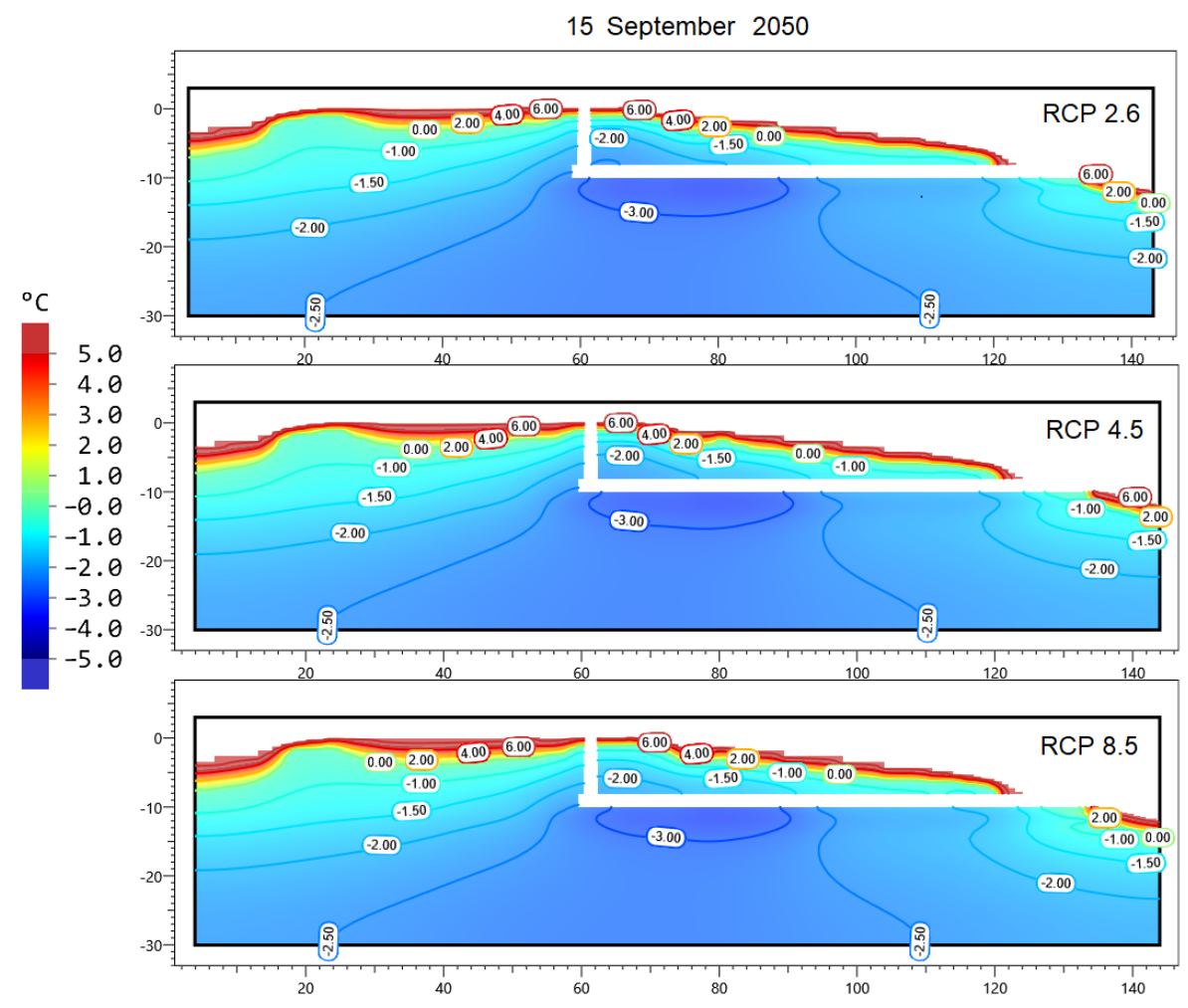

(d)

Figure 4. Expected ground temperature distributions along with line $A B$ of the ice cellar for (a) 15 March 2050, (b) 15 September 2050 and along with line BC of the ice cellar for (c) 15 March 2050, (d) 15 September 2050.

As shown in Figure 4, the thermal distribution of the soil temperatures varies only slightly depending on a climate scenario. This is due mostly to small differences between the predicted trends of the MAAT variations and the differences between the current and assessed values of the air temperature. If comparing to the baseline period it rises by 3.5-5.0 ${ }^{\circ} \mathrm{C}$ by the middle of the 21 st century depending on a scenario, then the dispersion between temperatures of different scenarios will be only $1.5^{\circ} \mathrm{C}$.

Comparison of the current and assessed section of the temperature field for the warm period shows that the temperature of frozen soils will rise in average by $0.5^{\circ} \mathrm{C}$ : from -2.3 to $-2.0^{\circ} \mathrm{C}$ for the soils covering the chambers in the central part, and from 3.0 to $2.5^{\circ} \mathrm{C}$ for the soils under the cellar facilities (Figure $4 \mathrm{a}-\mathrm{d}$ ). Changes of temperature of the underlying soils correspond to changes of the mean annual permafrost temperature, as they lie below the layer of the annual temperature variation, which we can observe in the winter section (see Figure $4 \mathrm{a}, \mathrm{c}$ ). For the winter period, we can also highlight that by 2050 , the temperature of the ground adjacent to the cellar walls will rise approximately by $1{ }^{\circ} \mathrm{C}$, from -5.0 to $-4.0^{\circ} \mathrm{C}$. The depth increment of the seasonal thawing of soil will depend on the lithological composition of sediments overlaying the ice cellar; in 2050 it is assumed as follows:

- $\quad 1.18$ to $2.16 \mathrm{~m}$ for the RCP 2.6 scenario;

- 1.19 to $2.53 \mathrm{~m}$ for the RCP 8.5 scenario.

\section{Discussion}

\subsection{Future of the Ice Cellar in Lorino}

The computer simulation considered three different scenarios of climate change. Results of the predictive simulation demonstrate notable but not critical changes of the thermal state of frozen soils for the ice cellar. However, the current simulation does not include a number of scenarios, related with the human-induced effect on the ice cellar operation. In 
actual practice, incorrect operation of an underground storage facility and disturbance of the ventilation regime can influence its stability even more than any climate changes.

Despite the preventive measures taken by the local whaling community to maintain the cellar's operating condition, a common negligence can cause thawing of soils and result in the ice cellar collapse. Among main problems of a cellar operation, we can mention uncontrolled opening of doors during summer, performing of repair works in summer and vehicles passing over the cellar roof. Most probable, those violations were the cause of a partial collapse and flooding of the southern part of the facility along the AB line (Figure 5).

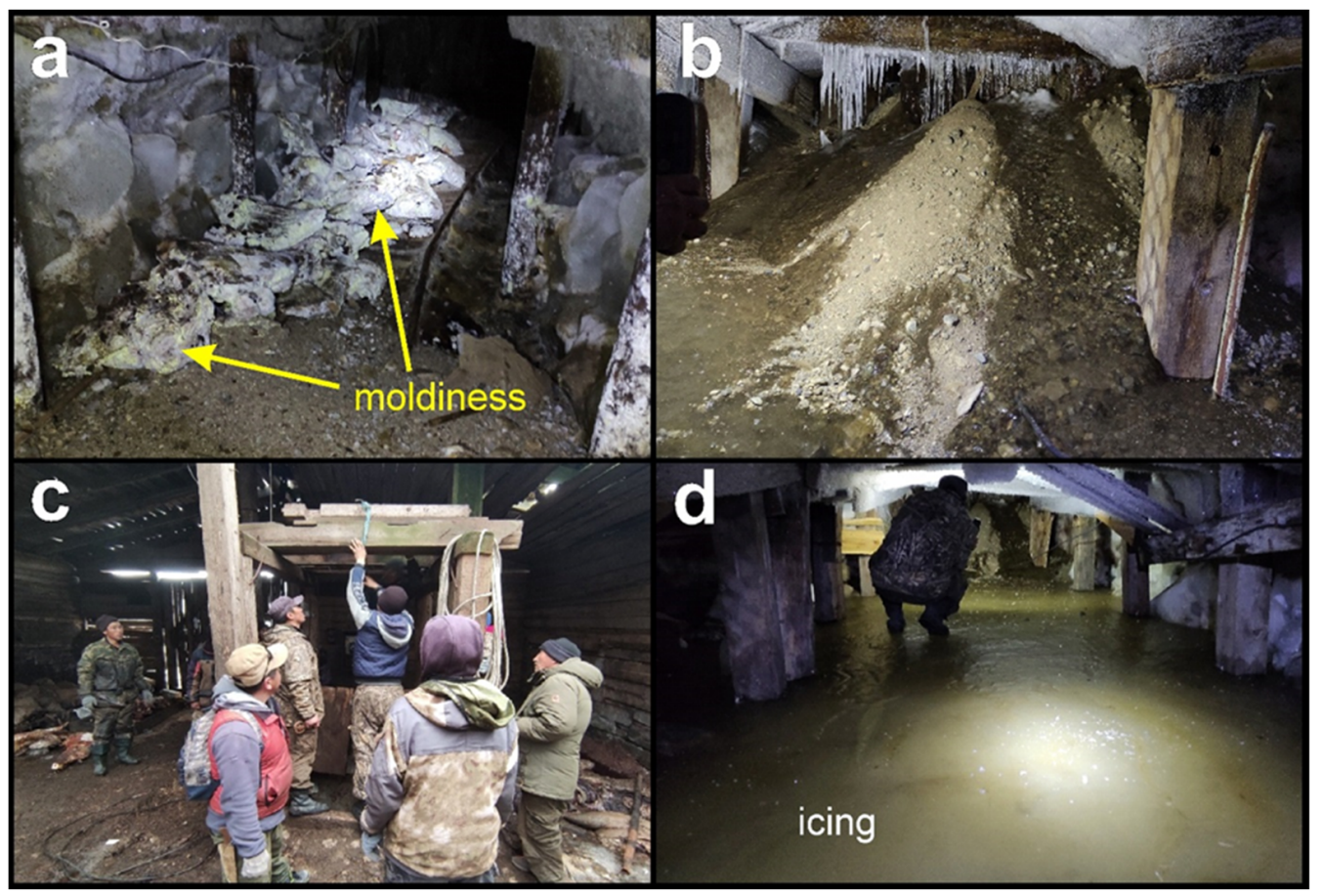

Figure 5. The stability issues for the Lorino ice cellar: (a) spoiling of the stored meat due to internal air temperature increasing, (b) ground collapse near the southern entrance of the ice cellar, (c) whale hunters lower a man on rope in the vertical shaft (during August of 2021, that was the only way to access the ice cellar) and (d) $1 \mathrm{~m}$ thick icing in the tunnel of the ice cellar formed after groundwater flooding and consecutive freezing. Photos by A. Maslakov, 2021.

As we mentioned above, the temperature of ground close to the cellar walls will rise by $1^{\circ} \mathrm{C}$ in winter, which can be explained by the temperature rise during the cold season. Growth of the winter air temperature decreases the efficiency of the natural winter ventilation and demands new activities to cool the frozen soils. Among these activities, we can mention the following: (a) forced ventilation of the cellar during winter, (b) regular snow clearing from the surface above chambers and corridors of the storage facility and (c) installation of thermosyphons.

\subsection{Issues and Limitations of the Computer Model}

The present work is the first to present a computer model of an ice cellar with numerical simulation of the 3D distribution of temperature field of soils. The authors are planning to further improve and update the simulation as new data arise. Furthermore, within the frames of the given simulation, the human-induced influence and various scenarios of incorrect operation of the cellar can be considered in future. Presented below are the current assumptions, adopted for simulation.

For our numerical simulation, we used data on thermophysical properties of soils, gathered more than 30 years ago. We suppose that new geologic surveys and updating of physical parameters of soils are necessary. These will allow for refining the computer 
simulation and improving the further thermal prediction of the cellar state. Moreover, new surveys will provide for updating the 3D geologic model.

The initial temperature field of soils was also set based on the out-of-date results of temperature monitoring [28]. Initial soil temperature was specified as $-3{ }^{\circ} \mathrm{C}$, which corresponds to the temperature at the depth of zero annual amplitude. However, in order to perform more accurate simulation, we need updated measuring of soil temperature by depths. The measurements are to be taken in several boreholes, if we want the initial spatial temperature in a thermal prediction to be more accurate. These data will also provide for updating other parameters of the computer model.

The model adopts a mean winter value of snow density, which was fitted following the results of its calibration in natural environment. We need to conduct repeated snow surveys for more precise estimations of snow cover temporal dynamics, its spatial distribution and thermal properties.

The thermal state of the ice cellar during the ventilation process was specified as an average obtained through monitoring with four temperature probes, which are located in the central part, lateral gallery and at both the exits from the storage facility [10]. Moreover, temperature variations inside tunnels and chambers do not take into account change in the air warming trend. Actually, temperature in the ice cellar can significantly vary between different chambers and along the whole length of the cellar. It is required to install more temperature probes in all compartments and throughout the whole length of the cellar. This will provide for updating the thermal effect of the cellar on soils and improving the computer simulation. This will also help in finding the relation between the temperature fluctuations inside the cellar and the outside air temperature.

The initial date for simulation is 2014, as that was the year when the first temperature probes were installed in the cellar. When the relation between changes of the air temperature and ice cellar temperature is identified, we will be able to perform a retrospective forecast starting from the earlier years, with the account for the actual weather data.

Conducting a good-quality permafrost forecast using specialized simulation applications depends largely on the quality of raw data, on thoroughness of description of heat exchange parameters and their variation in time. For many heat exchange parameters, such as snow cover, solar radiation, etc., we have not found reliable trends over time; in some cases, they appear statistically insignificant, also due to the insufficient observations. This degrades the quality of estimation of the expected changes in non-temperature climatic parameters and affects the permafrost forecast. Particularly important distortions can result from incorrectly defined function of the thermal resistance of snow. To a great extent, complexity of computer simulations of natural systems is explained by the stochastic nature of data for many input parameters. Further development of approaches to thermal predictions should consider uncertainties and deviations in the results of simulations, caused by instability of environmental conditions; we also deem it necessary to improve the procedure of adjusting the input data related to vegetation, snow cover, thermophysical properties of soils and other parameters [42].

\subsection{Ensuring Energy Sustainability and Food Security for Lorino}

The power-supply system of Lorino, as well as of other settlements throughout the Chukchi Peninsula, absolutely depends on imported fuel: coal and diesel oil. Lack of alternative energy sources makes this region vulnerable to irregularity of supply and possible technological accidents at energy facilities. Despite of the great potential of wind energy and proximity of hot springs [43], the government arrangements on providing the isolated settlements with energy from alternative sources are limited to just plans and intentions [44,45].

Despite of great dependence on imported food products, a significant part of the diet of Chukotka indigenous people consists of the local traditional food: berries, fish, marine animals, etc. [46]. However, their long-term storage also demands energy supply. Against the current social and economic background, underground storages in permafrost can serve 
as an alternative mean to keep foodstuff in the event of power failures. At the moment, the ice cellar is the only option for storing the feedstuff at the polar fox farm of the Lorino settlement. Purchasing and installation of reefer containers demand great financial costs. Because of the isolated location of the settlement from main economic centers, the current energy tariffs for entities is an order of magnitude greater than the Russian average [21]. Under such circumstances, operation of reefer containers can turn an unaffordable burden for the local budgets.

Numerical simulation has demonstrated that the climate-induced changes of thermal state of permafrost around the ice cellar will result in noticeable but not critical changes in soil temperature for stability of the facility by the middle of the 21st century. Under the conditions of correct operation and on-time implementation of the above measures to decrease the permafrost temperature, the ice cellar in Lorino can be operated by the middle of the 21st century, even taking into account consequences of climate changes.

\subsection{Further Development of the Research}

This study has revealed several potential directions of further research. The limitations of current computer model should be reduced for the increasing of model validity. To do this, we must obtain new data on thermophysical properties of soils and temperature by the depth of the ground. Additionally, we must obtain more data on the temperature inside the ice cellar to get the relation between changes in the air temperature and ice cellar temperature. Alternatively, we should consider multiphysics simulation with an explicit heat interaction between the air inside the ice cellar and the surrounding soils.

Establishing the network of energy-independent ice cellars can mitigate the acute problem of dependence of remote isolated Arctic communities from fossil fuel. The modern engineering technologies and new materials allow for a more effective use of natural cold for food preservation. The development of modern designed ice cellars along with the introduction of renewable energy production [47] may reduce carbon footprint from the Arctic communities [48,49], which is not well estimated yet [50]. Another potential research direction is assessment of economic effect from introduction of reefer containers in small communities instead of collapsed ice cellars. Our studies demonstrate that further development of research requires the combination of social, economic and engineering approaches as well as closer interaction of all stakeholders-indigenous peoples, industry and government.

\section{Conclusions}

Using the Frost 3D software, we created the first computer simulation of thermal state of the frozen soils surrounding an ice storage facility. The most difficult task when preparing the simulation was the correct identification of boundary conditions between the underground facility walls and surrounding soils. Due to the specific conditions of ventilation of the storage facilities during the cold months, the cooling effect of the ice cellar on soils could vary significantly in different parts of the cellar. Furthermore, the variation of ventilation temperature due to the warming trend was not taken into account. Nevertheless, we considered the lower cooling effect of the ice cellar than in natural environment, where the heat exchange coefficient for the scenario of free convection indoors was taken as $8.7 \mathrm{~W} /\left(\mathrm{m} \cdot{ }^{\circ} \mathrm{C}\right)$, and the air temperature inside the underground storage in the process of ventilation was $-5.8^{\circ} \mathrm{C}$ or higher.

According to the results of the computer simulation, the temperature of the frozen soils under the storage facilities, lying below the layer of the annual temperature variation, is $-3{ }^{\circ} \mathrm{C}$. Forecast of the soil temperature variations, based on climate changes, showed that by 2050, the temperature of frozen soils around chambers and corridors of the ice cellar will rise by $0.5^{\circ} \mathrm{C}$, and the depth of seasonal thawing from the ground surface will increase up to $3.7 \mathrm{~m}$ depending on the climate scenario and soil type. These changes will degrade stability of the walls and roof of the storage facility; however, they will not be critical. The 
results of field studies demonstrated that the human-induced factor can influence to a greater extent on stability of the underground structures.

In order to maintain or even increase the stability of the ice cellar in Lorino, we propose the introduction of additional measures to cool the frozen soils at winter: forced winter ventilation of the cellar, regular snow clearing from the surface above the ice cellars and installation of thermosyphons.

Lorino is one of numerous isolated settlements in the Russian Arctic, dependent on the mainland in terms of food and energy supply. The population consists mostly of the northern indigenous people, and their traditional way of life is based on the natural resources, which makes them more vulnerable to the observed climate changes than other groups of the population [51]. Maintenance of the existing underground storages and perspective construction of new facilities will provide for reducing energy dependence and alleviating food problems for the population of remote settlements; ultimately, these solutions can enhance the quality of life in the Arctic.

Author Contributions: Conceptualization, A.M.; methodology, G.G., A.M. and D.E.; software, G.G. and D.E.; validation, K.S. and G.G.; formal analysis, K.S. and A.M.; investigation, K.S. and A.M.; resources, G.G. and D.E.; data curation, A.M. and D.E.; writing-original draft preparation, A.M., K.S. and G.G.; writing - review and editing, A.M., K.S. and G.G.; visualization, K.S. and G.G.; supervision, A.M. and D.E.; project administration, A.M. and D.E.; funding acquisition, A.M. and D.E. All authors have read and agreed to the published version of the manuscript.

Funding: This research was funded by State Assignment of the Laboratory of Geoecology of the Northern Territories, MSU Faculty of Geography, U.S. National Science Foundation awards OPP1304555 and 1836377.

Data Availability Statement: The data presented in this study are available on request from the corresponding author. The data are not publicly available due to LLC STC Simmakers policy. Operating with data requires Frost 3D software which provides by request here: https:/ / frost3d.ru/ accessed on 27 April 2021.

Acknowledgments: We would like to thank Mihail A. Dainiak for visualization assistance and Gennady M. Zelensky and Dmitry G. Zamolodchikov for field work administration.

Conflicts of Interest: The authors declare no conflict of interest. The funders had no role in the design of the study; in the collection, analyses, or interpretation of data; in the writing of the manuscript, or in the decision to publish the results.

\section{References}

1. Fernandes, J.; Mateus, R.; Gervásio, H.; Silva, S.M.; Bragança, L. Passive strategies used in Southern Portugal vernacular rammed earth buildings and their influence in thermal performance. Renew. Energy 2019, 142, 345-363. [CrossRef]

2. Nguyen, A.T.; Tran, Q.B.; Tran, D.Q.; Reiter, S. An investigation on climate responsive design strategies of vernacular housing in Vietnam. Build. Environ. 2011, 46, 2088-2106. [CrossRef]

3. Nocera, F.; Caponetto, R.; Giuffrida, G.; Detommaso, M. Energetic retrofit strategies for traditional sicilian wine cellars: A case study. Energies 2020, 13, 3237. [CrossRef]

4. Montazeri, H.; Montazeri, F.; Azizian, R.; Mostafavi, S. Two-sided wind catcher performance evaluation using experimental, numerical and analytical modeling. Renew. Energy 2010, 35, 1424-1435. [CrossRef]

5. Krupnik, I. Arctic Ethnoecology; Nauka: Moscow, Russia, 1989; 272p.

6. Yoshikawa, K.; Maslakov, A.A.; Kraev, G.N.; Ikuta, H.; Romanovsky, V.E.; Craig, J.G.; Klene, A.E.; Nyland, K.E. Food Storage in Permafrost and Seasonally Frozen Ground in Chukotka/Alaska communities. Arctic 2022, in press.

7. Melnikov, V.P.; Fedorov, R.Y. The role of natural cryogenic resources in the traditional life support systems of the peoples of Siberia and the Far East. Bull. Tomsk State Univ. 2018, 426, 133-141. [CrossRef]

8. Yurtsev, B.A. Beringia and its biota in the Late Cenozoic: Synthesis. In Beringia in the Cenozoic: Materials of the All-Union Symposium "Beringian Land and Its Significance for the Development of Holarctic Flora and Fauna in the Cenozoic"; Kontrimavichus, V., Ed.; DVNTs of the USSR Academy of Sciences: Khabarovsk, Russia, 1973; pp. 202-212.

9. Elias, S.A.; Short, S.K.; Nelson, C.H.; Birks, H.H. Life and times of the Bering land bridge. Nature 1996, 382, 60-63. [CrossRef]

10. Maslakov, A.A.; Nyland, K.E.; Komova, N.N.; Yurov, F.D.; Yoshikawa, K.; Kraev, G.N. Community ice cellars in eastern Chukotka: Climatic and anthropogenic influences on structural stability. Geogr. Environ. Sustain. 2020, 13, 49-56. [CrossRef] 
11. Huang, J.; Zhang, X.; Zhang, Q.; Lin, Y.; Hao, M.; Luo, Y.; Zhao, Z.; Yao, Y.; Chen, X.; Wang, L.; et al. Recently amplified arctic warming has contributed to a continual global warming trend. Nat. Clim. Chang. 2017, 7, 875-879. [CrossRef]

12. Masson-Delmotte, V.; Zhai, P.; Pirani, A.; Connors, S.L.; Péan, C.; Berger, S.; Caud, N.; Chen, Y.; Goldfarb, L.; Gomis, M.I.; et al. IPCC, 2021: Climate Change 2021: The Physical Science Basis. Contribution of Working Group I to the Sixth Assessment Report of the Intergovernmental Panel on Climate Change; Cambridge University Press: Cambridge, UK, 2022; in press, Available online: https://www.ipcc.ch/report/ar6/wg1/downloads/report/IPCC_AR6_WGI_Citation.pdf (accessed on 25 January 2022).

13. Biskaborn, B.K.; Smith, S.L.; Noetzli, J.; Matthes, H.; Vieira, G.; Streletskiy, D.A.; Schoeneich, P.; Romanovsky, V.E.; Lewkowicz, A.G.; Abramov, A.; et al. Permafrost is warming at a global scale. Nat. Commun. 2019, 10, 264. [CrossRef]

14. Abramov, A.; Davydov, S.; Ivashchenko, A.; Karelin, D.; Kholodov, A.; Kraev, G.; Lupachev, A.; Maslakov, A.; Ostroumov, V.; Rivkina, E.; et al. Two decades of active layer thickness monitoring in northeastern Asia. Polar Geogr. 2021, 44, 186-202. [CrossRef]

15. Kintisch, E. These Ice Cellars Fed Arctic People for Generations. Now They're Melting. Available online: https://www. nationalgeographic.com/news/2015/10/151030-ice-cellar-arctic-melting-climate-change/ (accessed on 26 January 2022).

16. Klene, A.E.; Yoshikawa, K.; Streletskiy, D.A.; Shiklomanov, N.I.; Brown, J.; Nelson, F.E. Temperature regimes in traditional Iñupiat ice cellars, Barrow, Alaska, USA. In Proceedings of the Tenth International Conference on Permafrost, Salekhard, Russia, 25-29 June 2012; The Northern Publisher: Salekhard, Russia, 2012; Volume 4, pp. 268-269.

17. Yoshikawa, K.; Osipov, D.; Serikov, S.; Permyakov, P.; Stanilovskaya, J.; Gagarin, L.; Kholodov, A. Traditional ice cellars (Lednik, Bulus) in Yakutia: Characteristics, temperature monitoring, and Distribution. Arct. XXI Century Environ. Sci. $2016,1,15-22$.

18. Nyland, K.E.; Klene, A.E.; Brown, J.; Shiklomanov, N.I.; Nelson, F.E.; Streletskiy, D.A.; Yoshikawa, K. Traditional Iñupiat ice cellars (SIG̣̣UAQ) in Barrow, Alaska: Characteristics, temperature monitoring, and distribution. Geogr. Rev. 2017, 107, 143-158. [CrossRef]

19. The Number of Permanent Population of the Russian Federation by Municipalities on 1 January 2021. Available online: https: //rosstat.gov.ru/storage/mediabank/MZmdFJyI/chisl_\%D0\%9C\%D0\%9E_Site_01-01-2021.xlsx (accessed on 27 April 2021).

20. Goncharov, R.V.; Dankin, M.A.; Zamyatina, N.Y.; Molodtsova, V.A. Cathedrals in the desert or support bases? Typology of settlements in the Russian Arctic by the nature of the relationship with the surrounding area. Urban Stud. Pract. 2020, 5, 33-56.

21. Weingartner, K.A.; Antonov, E.V.; Maslakov, A.A. Assessing Energy Security in Nome and Lavrentiya. In Urban Sustainability in the Arctic: Measuring Progress in Circumpolar Cities; Berghahn Books: Providence, RI, USA, 2020; pp. 165-195.

22. Kobysheva, N.V. Climate of Russia; Gidrometeoizdat: Saint-Petersburg, Russia, 2001; p. 651.

23. Altynov, A.I.; Alyabina, I.O.; Arakcheev, A.N.; Ashik, A.M.; Baburin, V.L.; Badina, S.V.; Barsova, N.Y.; Baryshev, I.B.; Belousov, S.K.; Berdnikov, N.M.; et al. National Atlas of the Arctic; JSC "Roskartografiya": Moscow, Russia, 2017.

24. Kottek, M.; Grieser, J.; Beck, C.; Rudolf, B.; Rubel, F. World Map of the Köppen-Geiger climate classification updated. Meteorol. Z. 2006, 15, 259-263. [CrossRef]

25. Kolesnikov, S.; Plakht, I. Chukchi region. In Regional Cryolithology; Popov, A., Ed.; MSU: Moscow, Russia, 1989 ; pp. $201-217$.

26. Obu, J.; Westermann, S.; Bartsch, A.; Berdnikov, N.; Christiansen, H.H.; Dashtseren, A.; Delaloye, R.; Elberling, B.; Etzelmüller, B.; Kholodov, A.; et al. Northern Hemisphere Permafrost Map Based on TTOP Modelling for 2000-2016 at $1 \mathrm{~km}^{2}$ Scale. Earth-Sci. Rev. 2019, 193, 299-316. [CrossRef]

27. Chukotka Complex Department SevVostTISIZ. Object: “Adjustment of the layout and development project of the village of Lorino-The central estate of the state farm named after Lenin of the Chukotka district". In Technical Report on Engineering and Construction Surveys; Chukotka Complex Department SevVostTISIZ: Anadyr, Russia, 1979; 54p.

28. Chukotka Complex Department SevVostTISIZ. Object:"Point for processing and disposal of marine mammal products in the village of Lorino-The central estate of the state farm named after Lenin of the Chukotka district". In Technical Report on Engineering and Construction Surveys; Chukotka Complex Department SevVostTISIZ: Anadyr, Russia, 1984; 46p.

29. Maslakov, A.; Zotova, L.; Komova, N.; Grishchenko, M.; Zamolodchikov, D.; Zelensky, G. Vulnerability of the Permafrost Landscapes in the Eastern Chukotka Coastal Plains to Human Impact and Climate Change. Land 2021, 10, 445. [CrossRef]

30. Federal State Statistics Service. Available online: www.gks.ru (accessed on 31 March 2020).

31. Bulygina, O.N.; Razuvayev, V.N.; Trofimenko, L.T.; Shvets, N.V. Automated Information System for Processing Regime Information (AISPRI). Available online: http:/ / aisori.meteo.ru/ClimateR (accessed on 4 February 2021).

32. Pachauri, R.K.; Allen, M.R.; Barros, V.R.; Broome, J.; Cramer, W.; Christ, R.; Church, J.A.; Clarke, L.; Dahe, Q.D.; Dasqupta, P.; et al. Climate Change 2014: Synthesis Report. Contribution of Working Groups I, II and III to the Fifth Assessment Report of the Intergovernmental Panel on Climate Change; Pachauri, R., Meyer, L., Eds.; IPCC: Geneva, Switzerland, 2014; 151p.

33. Climate Change in Russia in the 21st Century (Models CMIP5). Available online: http://voeikovmgo.ru/?option=com_content\& view $=$ article \&id=613\&Itemid=236\&lang=ru (accessed on 20 October 2021).

34. Gosstroy of Russia. The Set of Rules of the Joint Venture 25.13330.2012. Bases and Foundations on Permafrost Soils; Gosstroy of Russia: Moscow, Russia, 2012; 64p.

35. Software Package for Thermal Calculations of Grounds FROST 3D. Available online: http://www.frost3d.ru (accessed on 15 October 2021).

36. Samarsky, A.A.; Gulin, A.B. Numerical Methods of Mathematical Physics; Nauchny Mir: Moscow, Russia, 2003; 316p.

37. Samarsky, A.A. Theory of Difference Schemes, 3rd ed.; Nauka: Moscow, Russia, 1989; p. 616.

38. Tsytovich, N.A. Mechanics of Frozen Soils; High School: Moscow, Russia, 1973; p. 448. 
39. Methodical Recommendations for the Use of Large-Diameter Metal Pipes in Conditions of Icing and Permafrost Soils. Available online: https:/ / docs.cntd.ru/document/1200035466 (accessed on 15 October 2021).

40. Kurtener, D.A.; Chudnovsky, A.F. Calculation and Regulation of Thermal Regime in Open and Protected Ground; Hydrometeoizdat: Leningrad, Russia, 1969; 299p.

41. The Set of Rules for Thermal Performance of the Buildings. Available online: https://docs.cntd.ru/document/1200095525 (accessed on 15 October 2021).

42. Pavlov, A.V.; Perlstein, G.Z.; Tipenko, G.S. Actual aspects of modeling and forecasting the thermal state of the cryolithozone in a changing climate. Cryosphere Earth 2010, 14, 3-12.

43. High-Temperature Hydrotermals of Chukotka. Institute of Volcanic Geology and Geochemistry. Available online: http://www. kscnet.ru/ivs/publication/volc_day/2003/art7.pdf (accessed on 20 October 2021).

44. On the Approval of the State Program of the Chukotka Autonomous Okrug Energy Efficiency and Energy Development of the Chukotka Autonomous Okrug for 2016-2020. Government of the Chukotka Autonomous Okrug. Available online: http://https://xn--80atapud1a.xn--p1ai/power/priority_areas/open-budget/government-programs/programmaenergoeffektivnost-i-razvitie-energetiki-chukotskogo-avtonomnogo-okruga.rtf (accessed on 25 October 2020).

45. Russian-Japanese Cooperation in the Field of Renewable Energy and Energy Efficiency. Ministry of Energy of the Russian Federation Russian Energy Agency. Available online: https://www.erina.or.jp/wp-content/uploads/2017/10/B-UMAKHANOV.pdf (accessed on 20 October 2021).

46. Bogoslovskaya, L.; Krupnik, I. Our Ice, Snow and Winds. Indigenous and Academic Knowledge on Ice-Scapes and Climate of Eastern Chukotka; Institut Naslediya: Moscow, Russia, 2013; 360p.

47. DeWitt, M.; Stefánsson, H.; Valfells, Á. Energy security in the Arctic. In Routledge Handbook of Arctic Security; Routledge: London, UK, 2020; pp. 91-101.

48. Ravasio, L.; Riise, R.; Sveen, S. Green Buildings in the Arctic region: A literature review. E3S Web Conf. 2020, 172, 16002. [CrossRef]

49. Moon, T.A.; Overeem, I.; Druckenmiller, M.; Holland, M.; Huntington, H.; Kling, G.; Lovecraft, A.L.; Miller, G.; Scambos, T.; Schädel, C.; et al. The expanding footprint of rapid Arctic change. Earth's Future 2019, 7, 212-218. [CrossRef]

50. López-Blanco, E.; Exbrayat, J.F.; Lund, M.; Christensen, T.R.; Tamstorf, M.P.; Slevin, D.; Hugelius, G.; Bloom, A.A.; Williams, M. Evaluation of terrestrial pan-Arctic carbon cycling using a data-assimilation system. Earth Syst. Dyn. 2019, 10, 233-255. [CrossRef]

51. Nuttall, M. An environment at risk: Arctic indigenous peoples, local livelihoods and climate change. In Arctic Alpine Ecosystems and People in a Changing Environment; Springer: Berlin/Heidelberg, Germany, 2007; pp. 19-35. 